\title{
Viestintäosaaminen muuttuu - pysyykö viestintäkoulutus muutoksessa mukana?
}

\section{Minna Kaihovirta-Rapo}

Viestintäosaamisen painopistealueet ovat murrosvaiheessa. Teknologiavälitteisen viestinnän määrän lisääntyessä ja organisaatioiden viestinnän siirtyessä yhä enemmän verkostoihin kasvavat myös vaatimukset yksilön viestintäosaamiselle. Globalisaatio ja tiukentunut taloustilanne tuovat mukanaan kilpailuasetelman, jossa vuorovaikutustaidot työnhakutilanteessa ja oman osaamisen markkinoiminen korostuvat. Organisaatioiden monimuotoistuessa tarvitaan myös yhä enemmän ryhmä- ja yhteistyötaitoja sekä puheviestintäosaamista, jotta työnteko sujuu erilaisia taustoja ja ikäryhmiä edustavien työtovereiden kesken.

Viimeisen kymmenen vuoden aikana vuorovaikutusosaamiselle asetetut vaatimukset ovat lisääntyneet huimasti. Muutos luo haasteita myös viestintäkoulutukselle. Ammattikorkeakouluissa tarjottavan viestinnän opetuksen tulisi tarjota koulutukseen osallistujille mahdollisuus kehittää taitojaan monipuolisesti ja siten, että hankittu osaaminen palvelisi työelämää mahdollisimman hyvin. Yhtälö on haastava mutta mahdollinen.

Tässä puheenvuorossa lähestyn tätä yhtälöä kahdesta näkökulmasta. Ensin tarkastelen aihetta oman työni kautta. Olen toiminut viestintäkouluttajana ja lehtorina ammattikorkeakoulussa liiketalouden alalla yli kymmenen vuoden ajan ja osallistunut opetuksen sisältöjen suunnitteluun ja kurssitavoitteiden määrittämiseen. Viestinnän ja vuorovaikutustaitojen opetuksen sisältöjä peilaan työelämän vaatimuksiin, joita Waldeck ym. (2012) ovat jäsentäneet Journal of Education for Business -julkaisussa ilmestyneessä artikkelissaan.

\section{Viestinnän opetuksen painotuksia ammattikorkeakoulussa}

Tässä esittämäni huomiot perustuvat Suomen suurimman ammattikorkeakoulun, Metropolia Ammattikorkeakoulun, ja sitä edeltäneen EVTEKammattikorkeakoulun liiketalouden alan opetukseen. Tarkasteltaessa 
viestintäkoulutusta ja puheviestinnän opetusta ammattikorkeakoulussa kymmenen vuoden aikajänteellä voidaan huomata useita muutoksia. Viestinnän opetuksen määrä on lisääntynyt ja toisaalta kurssien sisällöt monipuolistuneet. Viestinnän kursseilla myös pohjustetaan, jäsennetään ja analysoidaan yhä enemmän monen muun kurssin sisältöön tai opetusmenetelmiin liittyviä asioita. Kursseilla myös käytetään tilanteen mukaan rinnakkain kahta tai useampaa kieltä. Kymmenen vuotta sitten kursseilla ei ollut omaa kurssikirjaa, nyttemmin käytössä on Lohtaja-Ahosen ja Kaihovirta-Rapon (2012) teos Tehoa työelämän viestintään.

Ammattikorkeakoulujen opetussuunnitelmia uudistetaan 2-4 vuoden välein, ja jokaisen uudistuksen yhteydessä opetuksen sisältöä ja eri aineiden välisiä painotuksia pohditaan monesta eri näkökulmasta. Vuorovaikutustaitojen merkitys nousee suunnittelutyössä esiin usean oppiaineen yhteydessä, ja lähes kaikkien aineiden opettajat tunnistavat puheviestintätaitojen merkityksen muun muassa substanssiaineisiin liittyvän osaamisen osoittamisessa.

Opetussuunnitelmissa suuntaus on kulkenut erillisistä aineista aineiden integroinnin kautta tällä hetkellä sovellettavaan yhteisopettajuuteen. Kun siis kymmenen vuotta sitten vaikkapa puheviestinnän ja vuorovaikutusosaamisen perusteita opiskeltiin Suullisen viestinnän kurssilla, liitettiin seuraavaan opetussuunnitelmaan näitä taitoja osaksi Markkinointiviestinnän kurssia. Vuonna 2012 opintonsa aloittaneiden noudattamassa opetussuunnitelmassa puheviestintä on osa esimerkiksi Sijoitustuotteet ja niiden markkinointi -kurssia. Sitä opettavat yhdessä rahoituksen, englannin kielen ja viestinnän opettajat - kukin omasta näkökulmastaan aihetta lähestyen. Suurin muutos aiempaan on se, että opettajien yhteistyö on nyt tiiviimpää, ja yhä useammin opetustilanteessa paikalla on useampia opettajia tuomassa omaa näkökulmaansa aiheeseen.

Uusimpaan, syksyllä 2014 opintonsa aloittaneiden opiskelijoiden noudattamaan opetussuunnitelmaan on viestintäosaamisen kehittymiseen läpi opintojen kiinnitetty erityistä huomiota. Kaikki opiskelijat aloittavat oman viestintäosaamisensa jäsentämisen jo ensimmäisen lukukauden aikana. Tämä tapahtuu Orientointi ja ammatillisen osaamisen rakentaminen -kurssilla. Sen keskeistä sisältöä ovat puheviestinnän ja vuorovaikutusosaamisen taidot, mm. esiintymistaito, ryhmässä viestimisen perusteet sekä työnhakuun liittyvät taidot. Kurssin aikana jokainen opiskelija kokoaa sähköiselle alustalle osaamisportfolion. Sen tavoitteena on auttaa opiskelijaa hahmottamaan osaamistaan ja sen kehityssuuntia mutta toimia myös osaamisen ajantasaisena esitteenä vaikkapa työnhaun yhteydessä. Tehtävän ajoittaminen heti opintojen alkuvaiheeseen auttaa toivottavasti 
myös juurruttamaan myönteistä asennetta viestintäteknologiaa ja siihen liittyvän osaamisen kehittämistä kohtaan.

Kaikille opiskelijoille yhteinen, viiden opintopisteen laajuinen Liikeelämän viestinnän kurssi kokoaa yhteen sekä yksilön oman puheviestintäosaamisen kehittämistä, erilaisten viestintävälineiden käytön harjoittelua että teoreettisemman viestintäosaamisen näkökulmia. Kurssin sisältöjä ovat muun muassa esiintymisen ja ryhmäviestinnän taidot, kulttuurienvälisen viestinnän perusteet sekä yhteisöviestinnän keinot ja kanavat. Viestintäosaamiseen kohdistuvien odotusten nopea muutosvauhti näkyy kurssin sisältöön tarkoituksella väljästi kirjatussa ajankohtaiset viestintäaiheet -lisäyksessä.

\section{Viestinnälle oma sivuainekokonaisuus}

Viestinnän merkityksen korostumisesta kertoo myös se, että liiketalouden opiskelijat ovat voineet vuodesta 2013 alkaen valita Metropoliassa 15 opintopisteen laajuiseksi sivuainekokonaisuudeksi viestinnän. Koska kyse on ammattikorkeakoulun opiskelijoista, kokonaisuuden valitsevilla opiskelijoilla on taustallaan hyvinkin erilaisia opintoja. Osa on keskittynyt opinnoissaan taloushallintoon ja rahoitukseen, osa markkinointiin ja osa esimiestyöhön. Mukana on sekä nuoria, ensimmäistä korkeakoulututkintoaan opiskelevia opiskelijoita että työelämässä jo pidempään olleita aikuisopiskelijoita. Kokonaisuuden tavoitteena - ja osin ongelmanakin on tarjota erilaisilla profiileilla työelämään suuntaaville opiskelijoille kunkin viestintäosaamista monipuolistavaa ja syventävää sisältöä.

Käytän tässä esimerkkinä yhtä tämän sivuainekokonaisuuden valinneiden opiskelijoiden tehtävää. Tehtävässä kukin opiskelija valitsee perehtymisen kohteeksi itselleen uuden viestintäkanavan, perehtyy siihen ja sen jälkeen esittelee osaamistaan muille osallistujille. Perehtymiseen liittyy sekä teoreettinen että käytännöllinen osuus. Itsenäisen perehtymisen apuna on toinen opiskelija, jonka kanssa opiskelija muodostaa mentoriparin. Tehtävän etenemistä seurataan opettajan kanssa käytävissä henkilökohtaisissa ohjaustapaamisissa. Valittuja kanavia ovat olleet muun muassa Twitter, blogit ja video.

Opiskelijoiden oppimisprosessi ja osaamista esiintuovat lopputulokset ovat olleet opettajan näkökulmasta huikeaa seurattavaa. Tuotosten tekninen laadukkuus, niissä näkyvät innovaatiot ja oman persoonan rohkea hyödyntäminen yllättivät. Valittujen viestintäkanavien moninaisuus on tuonut nimenomaan tässä tehtävässä hyvin esille sen, miten monenlaiselle viestintäosaamiselle on tarvetta. Teoreettisen perehtymisen näkökulma 
puolestaan on auttanut opiskelijoita hahmottamaan esimerkiksi yritysten viestinnässään hyödyntämien sosiaalisen median kanavien määrän ja suosion huimaavaa kasvua.

\section{Monimuotoisuus tutuksi opintojen aikana}

Työelämän monimuotoisuutta pyritään tuomaan opiskelijoille tutuksi monella tavalla jo opintojen aikana. Uusimmassa opetussuunnitelmassa usealla kurssilla opetetaan rinnakkaiskielisesti, kahden eri kulttuuritaustaa edustavan opettajan opettaessa yhdessä. Kursseilla on jonkin verran myös yhdessä sekä nuoria että aikuisopiskelijoita.

Metropoliassa kaikki liiketalouden opiskelijat osallistuvat intensiivimuotoiselle liiketoiminnan eettisyyttä käsittelevälle kurssille. Kaikki kurssin opettajat ovat vierailevia luennoitsijoita eurooppalaisista yhteistyökorkeakouluista ja heidän opettamansa ryhmät monikulttuurisia pienryhmiä. Jakson opetus- ja työkieli on englanti. Jokainen ryhmä esittelee oppimistuloksiaan kaikille yhteisessä julistenäyttelyssä. Kurssi ja erityisesti sen päätöstilaisuus luo mainiot edellytykset puheviestintätaitojen harjoittelemiselle kulttuurienvälisessä kontekstissa.

\section{Työelämässä tarvittava viestintäosaaminen}

Viestintäosaaminen on työnantajien keskeisimpiä vaatimuksia työntekijälle. Waldeck ym. (2012) toteavat artikkelissaan, että samalla kun teknologiavälitteisen viestinnän määrä kasvaa ja viestimme yhä monimuotoisemmissa ympäristöissä, kaipaavat myös viestinnän osaamisvaateet ajantasaistamista. Tarvitsemme jäsentynyttä tietoa siitä, millaista viestintäosaamista liike-elämässä menestyminen edellyttää. Waldeck ym. (2012) analysoivat populaarien aikakauslehtien artikkeleita, joista he tarkastelivat liike-elämän edellyttämiä vuorovaikutustaitoja. Analysoitavia julkaisuja olivat Forbes, Fast Company, Harvard Business Review, MIT Sloan Management Review, Traning, T+D, Enterpreneur, Inc, HR Magazine ja Business Week. Tutkimus rajattiin lehtien painettuihin versioihin. Tutkimuksessa analysoitiin yhteensä 347 artikkelia. Seuraavassa kuvataan Waldeckin ym. (2012) esittämä jäsennys.

Analyysin tuloksena viestintä- ja vuorovaikutusosaaminen osaaminen jäsentyi kuuteen eri ryhmään. Ensimmäinen ryhmä oli interpersonaalinen viestintä ja ihmissuhdeosaaminen, joka sisältää viestintäsuhteen luomiseen, ylläpitoon ja päättämiseen liittyviä taitoja. Toinen ryhmä oli välitettyyn viestintään liittyvä osaaminen, joka käsittää erilaisten viestintä- 
teknologisten välineiden tehokkaan ja tarkoituksenmukaisen käyttämisen. Nämä kaksi ryhmää olivat esiintymistiheydeltään merkittävästi yleisempiä kuin loput neljä ryhmää.

Kolmas ryhmä oli ryhmäviestintäosaaminen. Yksilöosaamisen ohella se sisälsi ryhmien sisäisen ja ryhmien välisen viestinnän tukemisen taitoja. Neljäs ryhmä oli innostuksen, luovuuden ja sisäisen yrittäjyyden (enterpreneurial spirit) viestiminen. Innostuksen ja luovuuden kohteina olivat niin oma työ, yritys, yrityksen tuotteet kuin uudet ideatkin.

Viidentenä ryhmänä mainittiin sanattoman viestinnän taidot; niistä nostettiin esiin etenkin monimuotoisen työskentely-ympäristön mukanaan tuomat haasteet ja jälleen yksilötaitojen ohella myös taidot auttaa ja tukea muita näissä taidoissa. Kuudes ryhmä oli puhumisen ja kuuntelemisen taidot. Näistä nostettiin erikseen esiin esiintymisen ja aktiivisen kuuntelemisen taidot sekä yksilötasolla että muiden auttamisnäkökulmasta.

Oli kiinnostava huomata, että vaikka kaikki ryhmät sisälsivät puheviestintäosaamista, ei käytetty luokittelu noudata puheviestintäosaamisen perinteistä jäsentelyä. Selkeimmin perinteisistä puheviestinnän osa-alueista erottui teknologian käyttämiseen liittyvä osaaminen, uudenlainen ryhmä oli myös innostuksen viestimisen taito.

\section{Kompetenssien ja opetuksen sisältöjen vastaavuus}

Interpersonaaliseen viestintään ja ihmissuhdeosaamiseen liittyvä osaaminen kehittyy ammattikorkeakoulun monimuotoisissa, käytännönläheisissä ja usein myös yritysyhteistyötä sisältävissä opintojaksoissa. Useat viestinnän kurssien puheviestintäharjoitukset tehdään pareittain tai pienryhmissä, toisen parin tai ryhmän toimiessa toisten osaamisen havainnoijina ja palautteenantajina. Nämä harjoitukset auttavat hahmottamaan puheviestintätaitojen vahvuuksia ja kehittymiskohteita. Opintojen ohjauksen työkaluna käytetään kahdenkeskisiä kehityskeskusteluja. Niissä opiskelija pääsee pohtimaan omaa kehittymistä ja sen mahdollisuuksia yhdessä ohjaavan opettajan kanssa. Kehityskeskustelut luovat myös valmiuksia käsitellä asioita analyyttisesti keskustelun keinoin.

Erilaisia ohjelmia, ohjelmistoja ja sähköisiä alustoja hyödynnetään lähes kaikilla liiketalouden kursseilla. Näkisin, että viestinnän kurssien tehtävänä on erityisesti jäsentää eri kurssien yhteydessä syntynyttä osaamista ja antaa valmiuksia oman osaamisen näkyväksi tekemiseen. Viestinnän sivuainekokonaisuuden valinneet pääsevät myös aidosti laajentamaan ja syventämään omaa osaamistaan muun muassa perehtymällä yhteen uuteen viestintäkanavaan. 
Ryhmäviestintään liittyvää puheviestintäosaamista karttuu usean eri oppiaineen ryhmätöitä suosivissa opetusmenetelmissä. Ryhmätehtävien laajuus ja kesto vaihtelevat muutamien viikkojen lyhyistä kokonaisuuksista aina koko lukuvuoden mittaisiin yritysportfolioon ja innovaatioprojektiin. Projektin päätösvaiheessa opiskelijat sekä saavat että antavat toisilleen palautetta ryhmän työskentelystä, myös viestintäosaamisen kehittymisestä. Viestinnän opintojaksojen tehtävä on auttaa opiskelijoita ymmärtämään ryhmäprosesseja ja niiden haasteita. Ryhmäviestintätaidoista esiin nousevat ryhmissä viestimisen edellyttämät puheviestinnän taidot, joiden monipuolisuutta ja kehittymistä opiskelijoita ohjataan havainnoimaan myös muiden jaksojen ryhmätöiden yhteydessä.

Waldeckin ym. (2012) tutkimuksen ehkä kiinnostavin oli neljäs ryhmä - innostuksen, luovuuden ja sisäisen yrittäjyyden viestiminen. Tässä taitoryhmässä näkyvät kaikkein selvimmin myös kulttuurierot tutkittujen lehtien julkaisumaiden ja Suomen välillä. Ehkäpä nämä taidot korostuvat erityisesti yhdysvaltalaisessa viestintäkulttuurissa, mutta ovat vasta rantautumassa suomalaiseen viestintäkulttuuriin.

Metropolia Ammattikorkeakoulun Liiketalouden yksikön vahvuus on opiskelijoiden persoonat ja erilaiset lähtökohdat huomioiva toimintakulttuuri. Se luo hyvät edellytykset tämän ryhmän taitojen kehittämiselle - suomalaisessa mittakaavassa. Opiskelijoille myös annetaan opintojen alusta asti monipuolisia työkaluja oman osaamisen esiin tuomiseen. Viestinnän kurssien myönteinen, salliva ja kannustava ilmapiiri on keskeisessä roolissa näiden taitojen kehittymisessä. Tähän liittyvää osaamista kehitetään lisäksi markkinointiin keskittyvien opiskelijoiden vaikuttavan viestinnän osiossa, jossa opiskelijat pitävät muun muassa vaikuttavia puheita ja saavat palautetta niistä.

Sanattoman viestinnän taidoissa korostuivat monimuotoisen työskentely-ympäristön mukanaan tuomat erityispiirteet (Waldeck ym. 2012). Metropolian liiketalouden opetustarjonnan ja käytettävien opetusmenetelmien monipuolisuus yhdistettynä monikulttuuriseen ja hyvässä yhteistyössä työskentelevään opetushenkilöstöön antavat monia mahdollisuuksia harjoitella monimuotoisessa ympäristössä toimimista. Opintoihin liittyvät kansainväliset projektit ja intensiivitoteutukset rikastavat jokaisen opiskelijan kontaktiverkostoa ja antavat arvokkaita kokemuksia niin kulttuurien kuin sukupolvienkin välisestä viestinnästä. Nämä eivät tokikaan synny sivutuotteina, vaan jalostuakseen osaamiseksi edellyttävät puheviestinnän teoriaperustan luomista ja opitun analysointia viestinnän jaksoilla. Tämän taitoryhmän opetuksessa muutos kymmenen vuoden takaiseen on ollut selvästi havaittavissa. 
Viimeisenä tutkimuksessa mainitut puhumisen ja kuuntelemisen taidot ovat olleet aina mukana viestinnän jaksojen sisällöissä. Näillä on edelleen oma, tärkeä paikkansa eikä sujuvan puhe-esityksen pitämisen merkitys ole oman kokemukseni mukaan häviämässä mihinkään. Tilanteessa uutta on se, että nyt nämä aiemmin suuressa roolissa olleet puheviestinnän perustaidot ovat kurssien sisällöissä mukana yhtenä monien joukossa, eivät enää pääroolissa.

\section{Mitä tästä eteenpäin?}

Näyttäisi siltä, että Metropolian liiketalouden viestinnän opetuksessa on pystytty varsin hyvin vastaamaan työelämän muuttuviin odotuksiin. Kaikki opiskelijat pääsevät kehittämään omia puheviestintätaitojaan ja vuorovaikutusosaamistaan riippumatta siitä, millaisia valintoja he opinnoissaan tekevät. Myös viestintäteknologiaan liittyvää osaamista karttuu opintojen aikana. Viestintään syventymiseen tarjotaan monenlaisia mahdollisuuksia yksittäisistä projekteista sivuainekokonaisuuteen ja viestintäaiheiseen opinnäytetyöhön asti.

Uskon, että korkeakoulusektorin muuttuva rahoitusmalli pitää omalta osaltaan huolta siitä, että opetuksen sisältöjen vastaavuutta työelämän tarpeisiin tullaan jatkossakin seuraamaan tarkasti. Tämä pätee sekä substanssiaineisiin että viestintä- ja vuorovaikutustaitojen opetukseen.

Iduillaan oleva yrityksille tarjottava lisä- ja täydennyskoulutus kertoo myös selkeää viestiä siitä, että henkilöstön kehittämiskohteiksi nousevat usein viestintä- ja vuorovaikutustaidot. Niin kauan kuin koulutuksella pystytään vastaaman henkilöstön kehittymistarpeisiin, riittää tälläkin saralla viestintäkoulutuksessa sopivasti innostavaa tekemistä.

\section{Kirjallisuus}

EVTEK-ammattikorkeakoulun opetussuunnitelmat vuosille 2006 ja 2007. [viitattu 10.9.2014]. EVTEK-ammattikorkeakoulu, Vantaa. Saatavana www-muodossa: <URL: http://opinto-opas.evtek.fi/3330.html>

Lohtaja-Ahonen, S. \& Kaihovirta-Rapo, M. 2012. Tehoa työelämän viestintään. Puhu kuulijalle, kirjoita lukijalle. 2. painos. Helsinki: SanomaPro.

Metropolia Ammattikorkeakoulun opetussuunnitelmat 2008. [viitattu 10.9.2014] Metropolia Ammattikorkeakoulu, Vantaa. Saatavana www-muodossa: <URL: http://opinto-opas-ops.metropolia.fi/index.php/ fi/16183/fi/44/LE08S1V/year/2008> 
Metropolia Ammattikorkeakoulun opetussuunnitelmat vuodesta 2009 alkaen. [viitattu 10.9.2014] Metropolia Ammattikorkeakoulu, Vantaa. Saatavana www-muodossa: <URL: http://opinto-opas-ops.metropolia.fi/ index.php/fi/16183/fi/56 >

Waldeck, J., Durante, C., Helmuth, B. \& Marcia, B. 2013.

Communication in a changing world: Contemporary perspectives on business communication competence. Journal of Education for Business 87 (4), 230-240. 